\title{
TEATER MUSIKAL JAKARTA
}

\author{
David Guntur Putra ${ }^{1)}$, Suryono Herlambang ${ }^{2)}$ \\ 1) Program Studi S1 Arsitektur, Fakultas Teknik, Universitas Tarumanagara, davidp.ta@stu.untar.ac.id \\ 2) Program Studi S1 Arsitektur, Fakultas Teknik, Universitas Tarumanagara, suryonoh@ft.untar.ac.id
}

\begin{abstract}
Abstrak
Pada era modern ini kegiatan wisata merupakan salah satu kebutuhan bagi masyarakat untuk melepas stress dan mencari suasana baru. Kegiatan wisata sendiri adalah kegiatan mencari hal baru yang berbeda dari kegiatan sehari hari yang sifatnya menyenangkan. Dalam konteks wisata kota, kegiatan wisata tidak dapat dilepaskan dari arsitektur. Kota pada umumnya sedikit memiliki sumber daya alam untuk mendukung kegiatan wisata, sehingga diperlukan campur tangan manusia untuk mewujudkanya. salah satu contoh sukses campurtangan arisitektur dalam wisata adalah pada museum Guggenheim di Bilbao. Museum Guggenheim di Bilbao yang sukses membangkitkan kota melalui wisata menjadi contoh peran arsitektur dalam wisata. Kota jakarta sebagai kota metropolis dan ibu kota negara indonesia memiliki beragam potensi wisata, dari banyaknya suku dan budaya yang berkumpul. Kota Jakarta sendiri dapat diibaratkan sebagai miniatur dari Indonesia karena keberagamanya. Banyaknya budaya yang dapat dipertunjukan ini memerlukan wadah yang cukup untuk menampilkanya. Pada kota jakarta sendiri sebagai kota metropolis juga belum memiliki wadah yang cukup untuk menampung potensi wisata kebudayaan ini. Berangkat dari kisah kesuksesan musium Guggenheim dan besarnya potensi buadaya jakarta maka hendaklah dibuat wadah wisata yang dapat menampung dan mempertunjukan keragaman budaya kota Jakarta.
\end{abstract}

Kata kunci: budaya, kota metropolis, pertunjukan, wisata

\begin{abstract}
In this modern era tourism activities are one of the needs for the community to release stress and look for a new atmosphere. The tourism activity itself is an activity to look for new things that are different from daily activities that are fun. In the context of city tourism, tourism activities cannot be separated from architecture. Cities generally have little natural resources to support tourism activities, so human intervention is needed to make it happen. one example of a successful architectural intervention in tourism is the Guggenheim museum in Bilbao. The Guggenheim Museum in Bilbao, which successfully raised the city through tourism, is an example of the role of architecture in tourism. The city of Jakarta as a metropolis and the capital city of Indonesia has a variety of tourism potential from the many tribes and cultures that gather. The city of Jakarta itself can be likened to a miniature of Indonesia because of its diversity. The many cultures that can be demonstrated require a sufficient container to display it. In the city of Jakarta itself as a metropolis city also does not have enough containers to accommodate the cultural potential of this tourism. Departing from the success story of the Guggenheim museum and the magnitude of the potential of Jakarta's buadaya, a tourism container should be created that can accommodate and demonstrate the cultural diversity of Jakarta.
\end{abstract}

Keywords: culture, metropolis, show, tourism

\section{PENDAhULUAN}

Ruang metropolis adalah sebuah pusat populasi besar yang terdiri atas kumpulan dari berbagai elemen masyarakat dalam lingkungan urban. Wisata adalah kegiatan perjalanan untuk menemukan sesuatu yang baru, entah itu suasana, pengalaman, pemandangan, den sebagainya yang bersifat menyenangkan. Dalam ruang mertropolis, elemen arsitektur menjadi faktor penarik wisatawan, karena pada lingkungan kota yang didominasi oleh bangunan padat dan tidak memiliki daya tarik alam. 
Jakarta, sebagai ibukota negara tidak hanya sebagai pusat pemerintahan saja, namun juga pusat perekonomian. Dengan pertumbuhan ekonomi yang kuat maka akan mendorong arus urbanisasi menuju kota Jakarta, hal ini menyebabkan meningkatnya kepadatan penduduk. Peningkatnya jumlah penduduk mengakibatkan kebutuhan kota akan makin meningkat, termasuk kebutuhan untuk wisata.

Arus urban menuju kota jakarta tidak hanya menambah jumlah penduduk di jakarta tapi juga kebergaman budayanya. Tanpa adanya wadah yang bisa menampung biasanya, keberagaman ini akan perlahan hilang dan berbaur dengan budaya kota pada umumnya.

Belajar dari kesuksesan museum Guggenheim di Bilbao dan besarnya potensi wisata metropolis di Jakarta maka dimungkinkan untuk membangun kawasan wisata yang dapat membangun citra Jakarta di dunia. Jakarta sendiri disebut sebagai The Big Durian, yang disandingkan dengan Big Apple New York. Keberagaman budaya dan karakter pada kota metropolis, menjadi potensi untuk ditonjolkan dalam bidang wisata.

Untuk membangun atraksi wisata dalam suatu kota, pertama perlu mengetahui karakter dan potensi wisata kota. Kota Jakarta merupakan salah satu destinasi utama bagi turis

Jakarta merupakan budaya campuran dari beragam etnis dan budaya. Dari zaman belanda Jakarta merupakan penarik pendatang dari seluruh nusantara. Selain merupakan campuran dari beragam etnis nusantara Jakarta juga banyak menyerap budaya luar seperti tiongkok, india, arab, dan portugis. Ragam kenudayaan ini kemudian dapat ditampilkan dalam seni pertunjukan.

Dalam seni pertunjukan pada dasarnya terbagi atas 3 kategori yaitu, pertunjukan musik, seni tari, dan pertunjukan drama. Penampilan Ke 3 kategori tersebut kemudian dapat digabungkan menjadi suatu pertunjukan yang lebih kompleks dalam pertunjukan seni teaterikal.Kota Jakarta sendiri terdapat beberapa peminat dari seni teater ini, diantaranya adalah beberapa grup teater ternama di Jakarta. (Tabel 1)

$\begin{array}{cc}\begin{array}{c}\text { Tabel 1. Beberapa Grup Teater Aktif di Jakarta } \\ \text { Nama grup }\end{array} & \begin{array}{c}\text { Anggota } \\ \text { Neater Ghanta }\end{array} \\ \text { Teater Alamat } & 30-60 \text { Orang } \\ \text { Te-40 Orang } \\ \text { Bumi Kalamtara } & 30-50 \text { Orang } \\ \text { Teater Sketsa Act } & 20-30 \text { Orang } \\ \text { Teater Galaxy } & 17-25 \text { Orang } \\ \text { Teater Fatima } & 15-20 \text { Orang } \\ \text { Teater Koma } & 60-80 \text { Orang }\end{array}$

Sumber www.seputarteater.wordpress.com

Dengan banyaknya group teater disimpulkan bahwa peminat teater di Jakarta cukup banyak namun, banyaknya grup theatre Jakarta ini biasanya terhenti pada jenjang SMA karna tidak ada wadah yang dapat menampung kreativitas teater.

Wadah untuk menampilkan kegiatan teater di Jakarta masih dinilai kurang untuk level kota metropolis. Terutama fasilitas penampilan untuk taraf internasional, untuk menarik turis dan pertunjukan kelas internasional. Maka dari itu diperlukan suatu wadah yang dapat menampung kegiatan teater dengan taraf internasional di Jakarta.

\section{METODE}

Metode yang digunakan adalah

1. Pengumpulan data melalui metode kualitatif melalui studi literatur sebagai pedoman menentukan rancangan dan kebutuhan ruang seperti: Neufert Architects' Data, Architectural Tourism: Building for Urban Travel Destination, Michael Barron-Auditorium Acoustics and Architectural Design, Theatre and Performance in Digital Culture, serta 
melakukan pengamatan data dengan melakukan survei Pada kawasan Gambir, Jakarta Pusat.

2. Menganalisa dan mensintesa data yang didapat dari sumber literatur dan lapangan yang kemudian dijadikan acuan dasar dalam mendesain.

\section{DISKUSI DAN HASIL}

\section{Architectureal Tourism}

Arsitetur pariwisata merupakan sebuah bentukan arsitektur yang dapat menarik pengunjung. arsitektural pariwisata berpengaruh terhadap lingkungan dan perekonomian lingkungan sekitarnya karena kegiatan wisata akan mempengaruhi kegiatan masyarakat didalamnya (Specht, 2014). Arsitektur pariwisata akan membutuhkan fungsi kegiatan yang beragam sebagai daya tarik dan fungsi yang dapat menakjubkan bagi pengunjung.

Bentukan arsitektur selain dipengaruhi masyarakatnya juga dipengaruhi trend jaman. Arsitektur memainkan peran yang signifikan dalam merancang bentuk destinasi yang unik dan mudah dikenali. Dalam arsitektur pariwisata fotografi dapat menyebarkan gambaran visual destinasi. Selain itu fotgrafi juga berkembang menjadi tujuan untuk datang ke destinasi tersebut. Wisata arsitektur memerlukan perkembangan, perubahan, suatu yang baru, karena Apa yang menjadi dikatakan hebat dulu bisa menjadi hal yang biasa di masa kedepannya. Keunikan tidak selalu berarti spektakuler, sementara spektakuler menyiratkan keunikan tertentu (Specht, 2014).

Mencontoh dari kesuksesan Museum Guggenheim yang telah berdiri kurang lebih selama 20 tahun, dan masih menjadi ikon kota bilbao. Menjadi bukti bahwa arsitektur memainkan peranan besar dalam mengubah citra kota melalui wisata (The Guardian, 2018). Museum ini dikatakan sebagai bangunan paling berpengaruh pada zaman modern.

\section{Seni Pertunjukan Teater}

Dalam seni pertunjukan merupakan ungkapan dari budaya untuk menyampaikan nilai nilai estetik, maupun norma norma yang berkembang pada wilayah dimana seni pertunjukan tersebut berada (Susetyo, 2007). Seni pertunjukan akan melibatkan berbagai karya seni didalamnya yang menjadikanya bentukan seni yang kompleks. Teater sendiri berasal dari bahasa inggris yaitu Theater atau Theatre. Kata teater diartikan sebagai tempat atau gedung pertunjukan (KBBI.web, 2018). Sedangkan menurut istilah teater adalah segala hal yang dipertunjukan di atas pentas untuk dikonsumsi oleh penikmatnya.

\section{Kebutuhan Ruang Teater}

Panggung pada seni pertunjukan teater menjadi orientasi utama. Panggung menjadi tempat berlangsungnya pentas dan pertunjukan teater. Pada mulanya panggung teater merupakan pertunjukan pada ruang luar, tapi seiirng berkembangnya teater maka kebutuhan ruang makin bertambah dan diperlukan ruang dalam untuk menampung penonton.

Beberapa elemen dasar pada teater untuk mendukung kegiatan pentas diantaranya

a. Depan dan Belakang Panggung yang menjadi orientasi utama pada bangunan teater. Bagian depan menjadi tempat dimana pengunjung dapat menonton pentas teater, sedangkan belakang panggung merupakan dapur dari teater yang menyiapkan pertunjukan

b. Tempat duduk penonton Pengaturan tempat duduk perlu diatur agar penonton dapat melihat dengan jelas pertujukan yang berlngsung dan bahkan seolah olah menjadi bagian dari pertujukan tersebut

c. Ruang sirkulasi sebagai ruang pergerakan. Terdapat beberapa hal yang menjadi bahan pertimbangan dalam merancang sirkulasi dalam bangunan, Yaitu; Aspek aspek estetis, keamanan, pandangan pada daerah sirkulasi, dan pencapaian. 
1. Sistem pencahayaan dalam gedung teater dapat dibagi menjadi beberapa bagian sesuai dengan fungsinya, diantaranya Lampu Rumah (General Lighing), Lampu Kerja (Task Lighing), Lampu panggung (Accent Lighing)

2. Pengendalian akustik untuk mengatur suara. Arsitektural diperlukan untuk mengatur suara dalam teater. Tujuanya adalah mengendalikan perpindahan suara dari satu bangunan ke bangunan lain dengan fungsi tertentu. pengendalian suara dilakukan dengan manipulasi jalur rambat suara, diantaranya pada plafond, pintu, jendela, dan lainya (Baron, 2009)

\section{Tapak Rancangan}

Di Jakarta sendri terdapat beberapa gedung auditorium untuk teater. Kebanyakan fasilitas ini tersebar pada kawasan Jakarta Selatan dan Jakarta Pusat. Kota Jakarta Pusat merupakan wilayah yang memiliki geografis yang sangat strategis di jantung ibukota. Sebagai wilayah yang memiliki kekhususan dibandingkan dengan wilayah lainnya. Selain itu Tempat ini juga menjadi pusat budaya dengan adanya Monas dan Musium Nasional.

Lokasi tapak rancangan tepatnya terletak pada wilayah Kecamatan petojo gambir, Jakarta Pusat (Gambar 1). Pada lokasi ini juga terdapat banyak tempat wisata yang menceritakan sejarah dan budaya Indonesia.
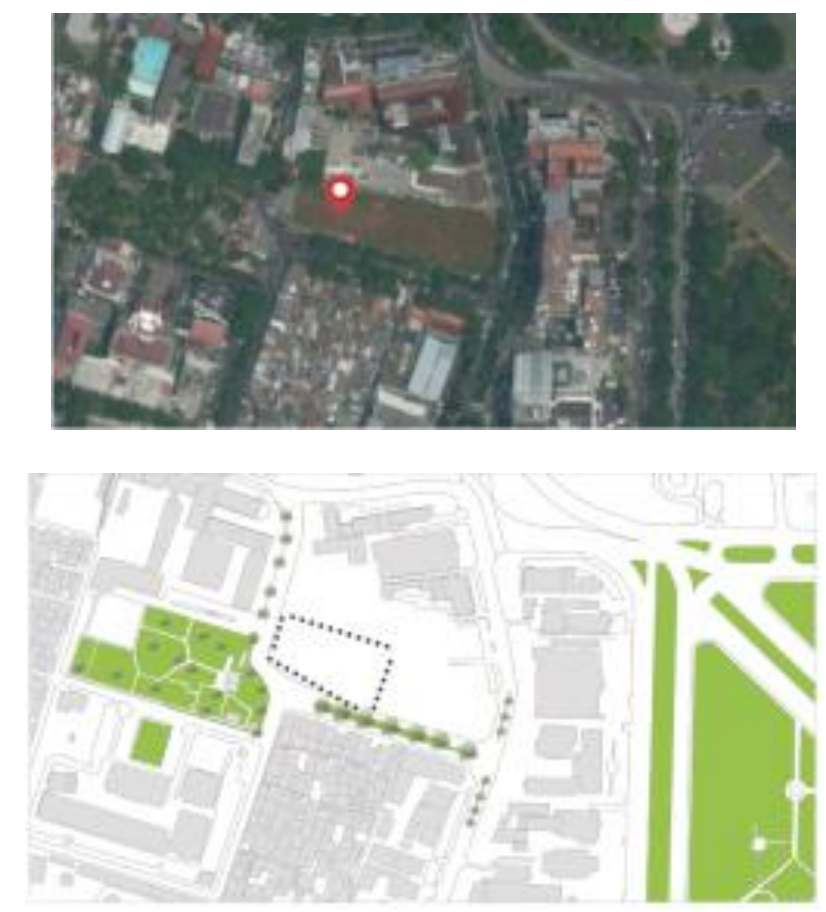

Gambar 1. Lokasi Tapak

Sumber: Google Earth

Lokasi tapak berada pada persimpangan jalan Tanah Abang I dan jalan Jahe Kober 5. Pada sisi utara tapak bersebelahan dengan ruko. Pada sisi selatan tapak akan berbatasan dengan gedung perkantoran. Sisi selatan dan barat tapak terdapat perumahan warga dan berhubungan langsung dengan jalan umum.

Pembanguan gedung teater pada lokasi tapak akan menghubungkan tempat tempat wisata sekitar yaitu pada kawasan monas, museum nasional, dan musium prasasti, (Gambar 2) yang membuatnya menjadi kawasan bertema wisata indonesia dari segi sejarah, dan kebudayaan pertunjukan. 


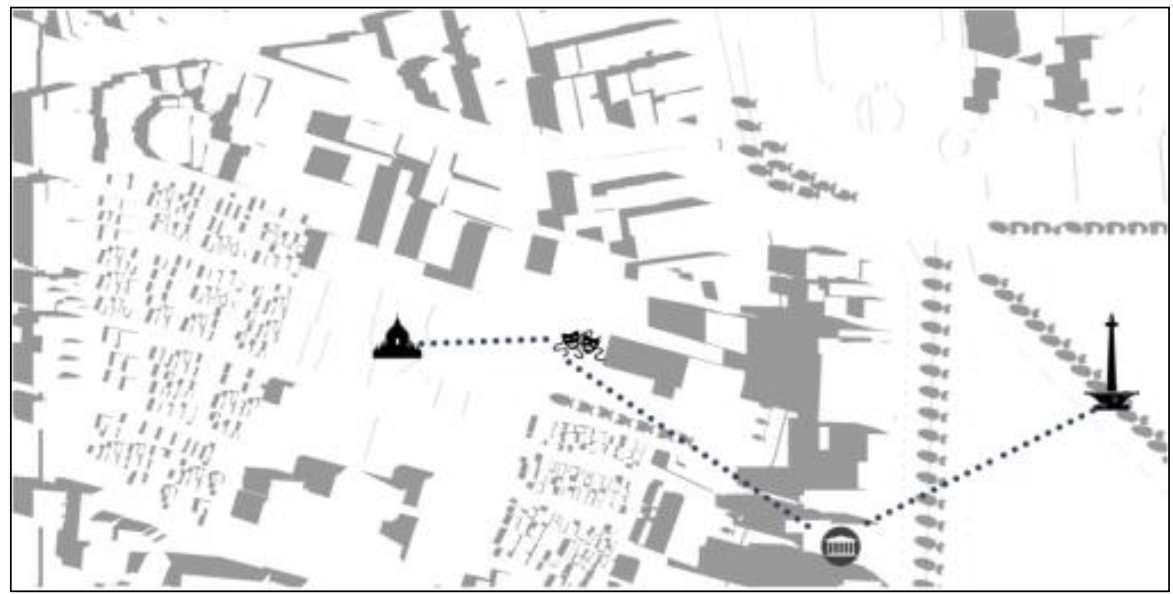

Gambar 2. Konsep Tapak

\section{Konsep Rancangan}

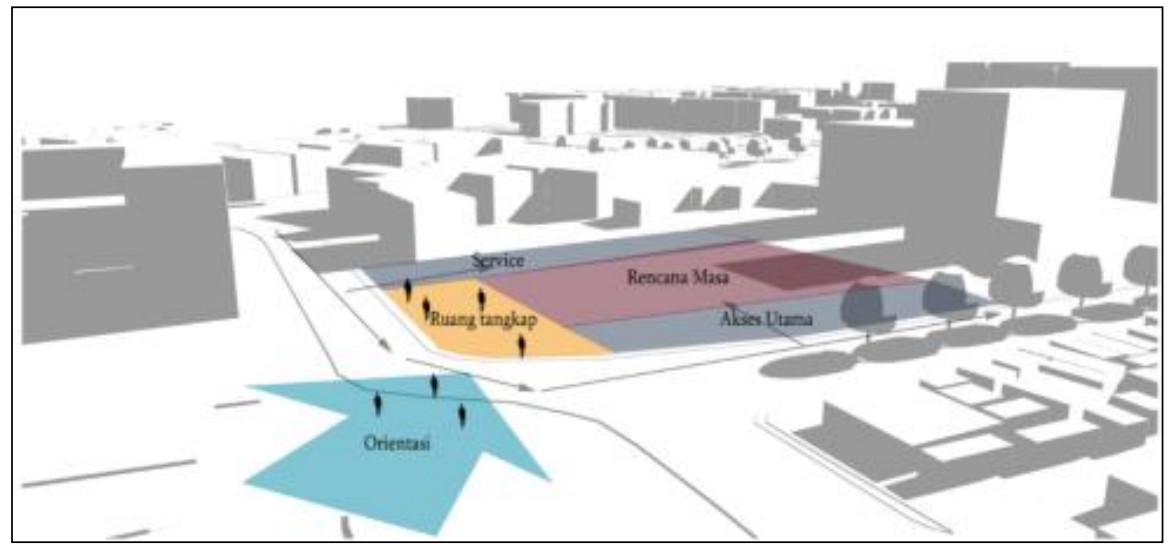

Gambar 3. Konsep Ruang Luar

Rancangan masa bangunan merespon lokasi tapak yang berada pada hook jalan dengan membuka sisi barat tapak untuk dijadikan areal tangkap pengunjung khususnya pejalan kaki (Gambar 3) . Dari hierarki jalan yang ada kemudian dapat ditentukan sisi pintu masuk utama bangunan, yaitu berada pada sisi selatan tapak. Pada sisi timur dan utara tapak yang tidak langsung bertemu dengan jalan umum dijadikan sebagai jalur sirkulasi menuju parkir, dan sirkulasi untuk service bangunan.

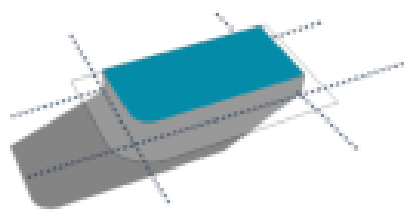

Futas tretar Gatuhin mengkati dari aksia tapk ekvisting untuk merepon karakter gatuhin knta

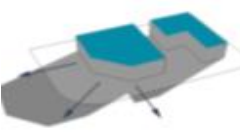

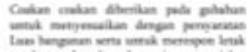

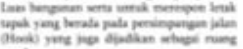

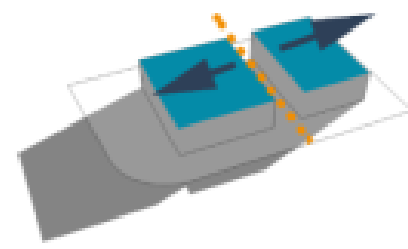

Mawe yang sodak mengikzti garis tapuak dikagi mesiadi 2 ghtuhan atas furguinga. bangunan uramu dan pendukeng
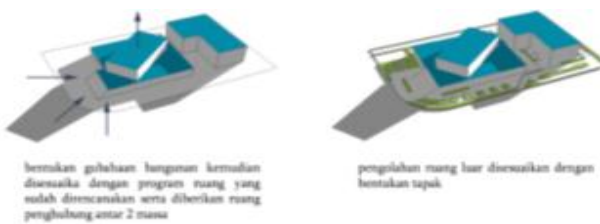

Gambar 4. Proses Gubahan Masa 
Dasar bentukan masa bangunan adalah persegi panjang mengikuti aksis kota, kemudian Masa banguan dibagi menjadi 2 masa terpisah agar masing masing zoning kegiatan tidak tercampur. Kemudian masa yang sudah terpisah dibentuk sesuai dengan orientasi pada hook jalan dan kebutuhan ruang. Konsep bentukan bangunan adalah panggung, dengan menggunakan masa lantai dasar sebagai pedestal (panggung) untuk masa bangunan utama Bentukan lantai dasar bangunan tetap mengikuti bentukan aksis perkotaan. Sedangkan masa auditorium sengaja dibentuk seperti sirip untuk mengundang perhatian. Masa banguan pendukung sengaja dibuat sederhana dan mengikuti aksis kota seperti masa lantai dasar agar tidak terlalu mencolok. Diantara masa utama dan masa pendukung diberikan taman sebagai ruang antara.

\section{Hasil Rancangan}

Berikut adalah hasil rancangan bangunan teater bedasarkan analisa kebutuhan ruang dan potensi tapak, yang kemudian mengasilkan bentukan solid, void pada ruang lantai rancangan. Bentukan akhir masa bangunan berorientasi pada hook yang memandang langsung taman prasasti (Gambar 5)

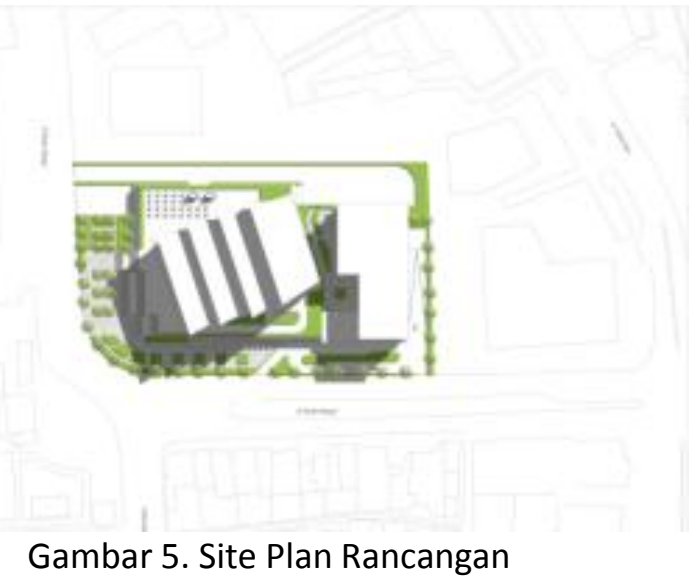

Desain pada lantai dasar digunakan sebagai zona sirkulasi dan publik untuk memudahkan akses pengunjung dan servis pementas ( Gambar 6). Lokasi pintu service utama diletakan pada sisi utara tapak yang menjadi sisi belakang sehingga bersifat tersembunyi, dan terpisah dari jalur publik. Ruang belakang panngung mengambil pada level lantai dasar dan basemen yang dijadikan sebagai trap room. Ini dimaksudkan untuk memudahkan dekorasi panggung dan memndahkan peralatan pentas ketika menyiapkan pertunjukan.

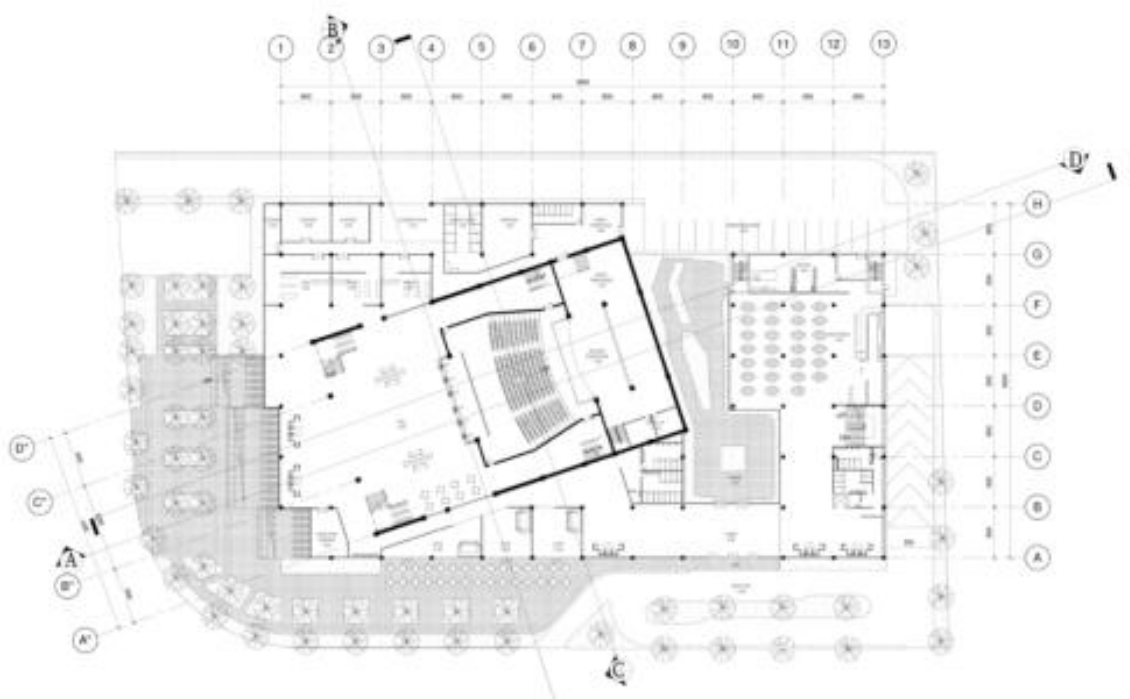

Gambar 6. Denah Lantai Dasar 
Lokasi pintu utama untuk memasuki ruang teater terletak pada lantai 2 sehingga panggung teater bisa berada pada level lantai dasar (Gambar 6 dan 7). Pada lantai dasar yang dijadikan Pedestal untuk lantai 2 ditutup dengan dak beton, yang kemudian dijadikan taman ruang terbuka.
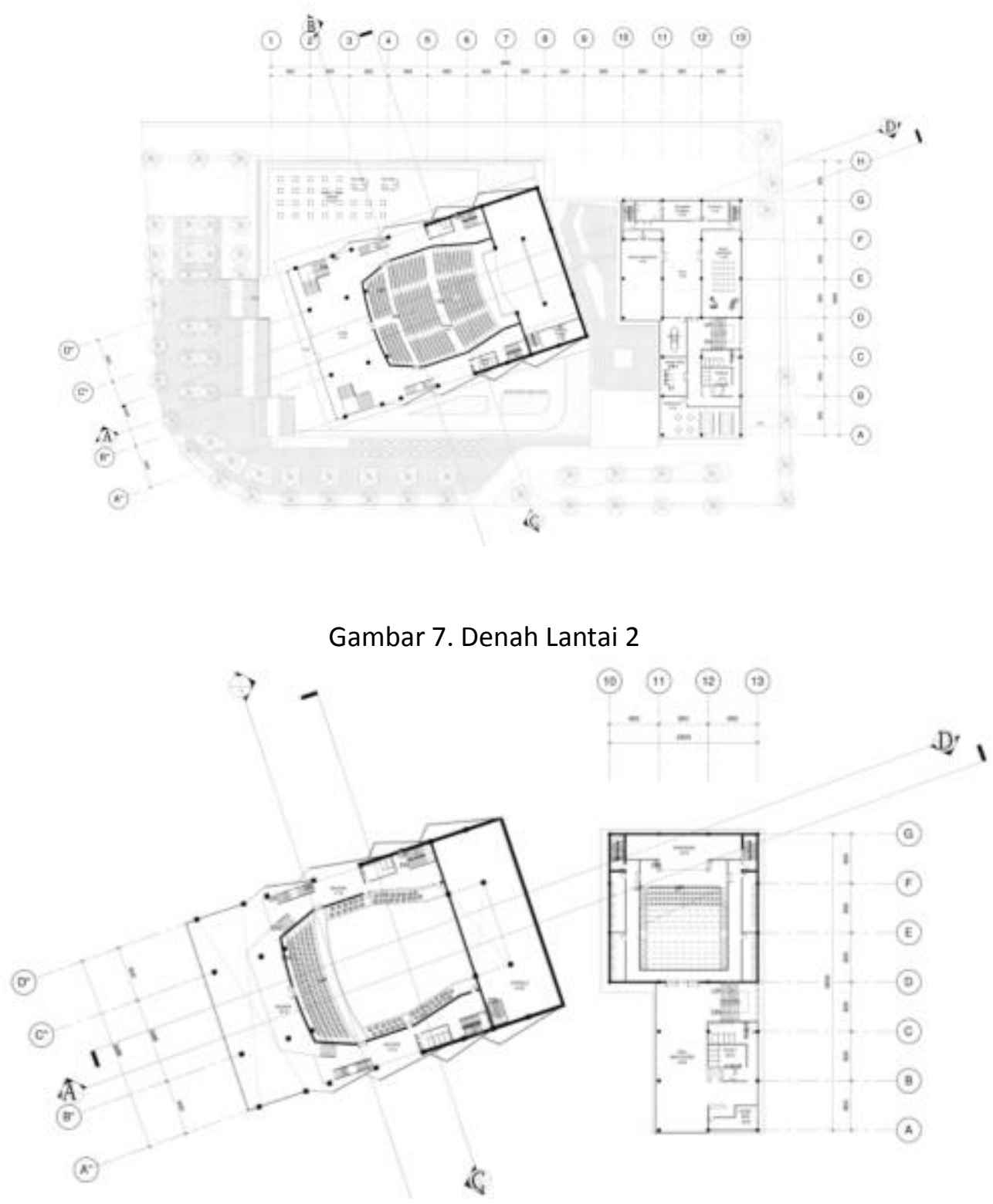

Gambar 8. Denah Lantai 3 


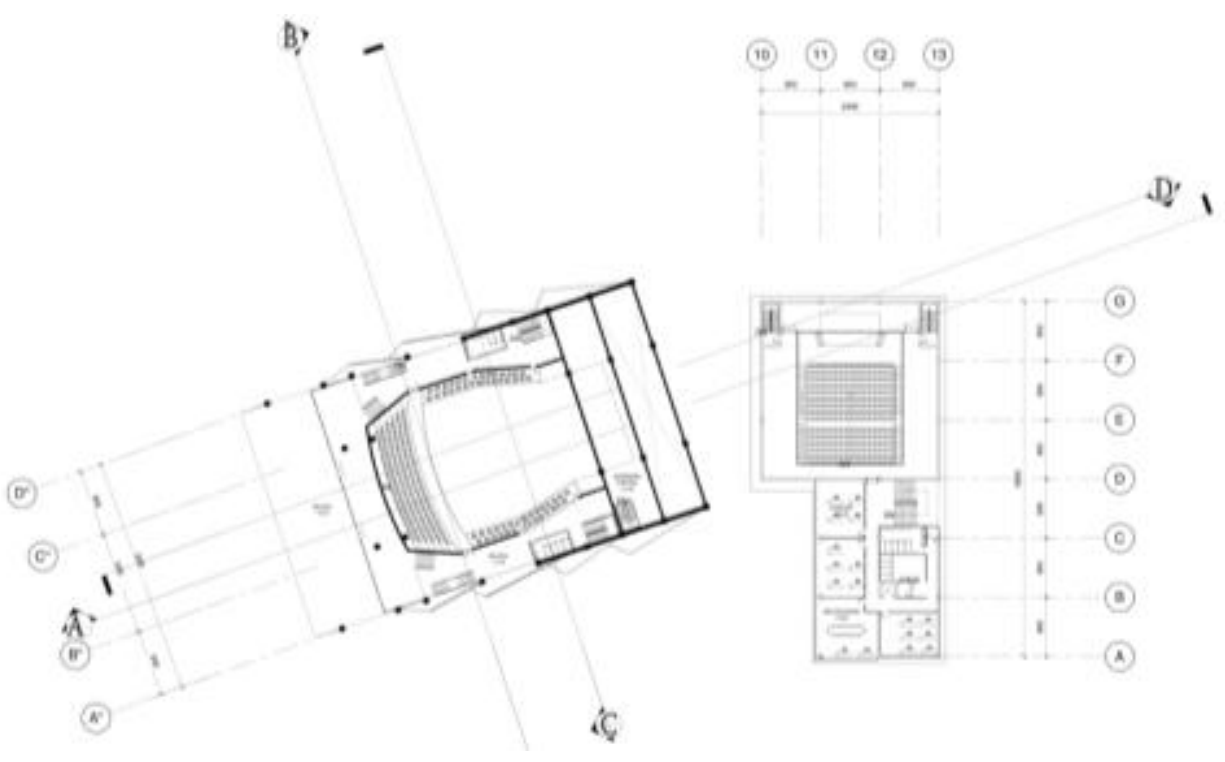

Gambar 9. Denah Lantai 4

Pada lantai 2, dan 3 dijadikan sebagai ruang untuk balkon teater utama (Gambar 8 dan 9). Total keluruhan kursi yang dapat ditampung dalam ruang teater utama termasuk pada ruang balkon adalah sekitar 1236 kursi penonton.

Pada masa bangunan pendukung diberikan ruang untuk latihan dan persiapan pentas. Diantaranya adalah ruang untuk dubbing, ruang latihan musik, ruang latihan menari, dan mini auditorium. Selain untuk mendukung keperluan panggung pada lantai dasar juga diberikan fungsi komersial seperti restauran dan pertokoan untuk kenyamanan pengunjung.

Struktur yang digunakan pada bentang lebar atap digunakan struktur space frame untuk mendapatkan lebar bentangan yang maksimal, dan lebih kokoh. Dari ruang atap menuju ke plafond sengaja diberikan sedikit jarak untuk membuat buffer udara sehingga ketika terjadi hujan tidak akan ada banyak efek suara yang ditimbulkan.

Pada plafond digunakan bahan Acoustic timber panel yang sengaja dibuat cembung untuk memaksimalkan penyebaran pantulan suara. Ketinggian plafond auditorium dari lantai sekitar $16 \mathrm{M}$ untuk memaksimalkan akustik suara (Gambar 10).

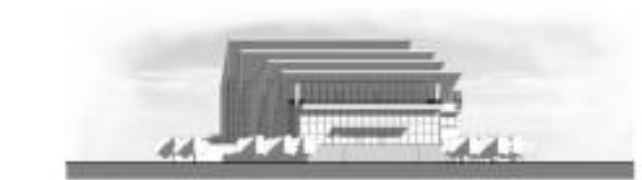

TnMpes,

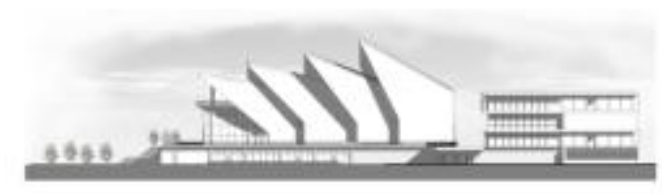

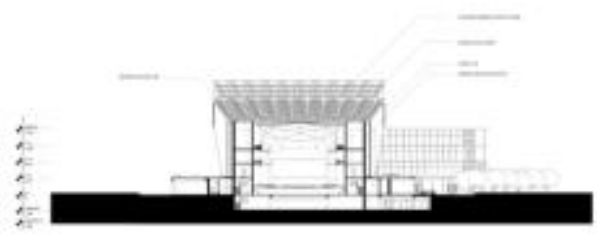

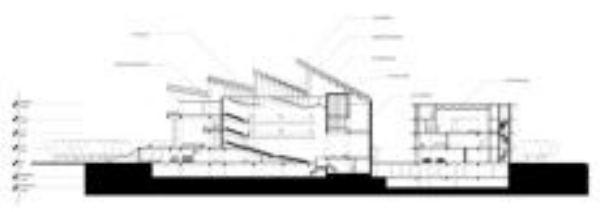

Gambar 10. Tampak dan Potogan 


\section{KESIMPULAN DAN SARAN}

Jakarta memiliki banyak rangam budaya dan kesenian tidak hanya dari dalam Jakarta tapi juga dari seluruh penjuru Indonesia karna arus urban yang kuat kearah Jakarta. Seluruh kesenian dan kebudayaan yang datang dari penjuru Indonesia ini perlu ditampung dan ditampilkan, sehingga kesenian dan krbudayaan ini tidak mati terbawa arus globalisasi.

Sebagai kota metropolis memerlukan wadah yang dapat menampung pertunjukan kesenian dan kebudayaan dari mancanegara. Sebagai ibo kota Jakarta sudah menjadi miniature Indonesia dengan keberagamanya. Pada wilayah Jakarta pusat dirasa sangat cocok untuk dibangun bangunan yang dapat mewadahi pertunjukan kesenian ini. Pada wilayah tersebut dapat dihubungkan antara bangunan yang akan dibangun, Wilayah monas, dan gedung museum Jakarta sebagai pusat budaya kota Jakarta.

Program proyek yang diusulkan untuk memenuhi tuntutan ini adalah sebuah ruang pertunjukan teater. Diusulkan bahwa kapasitas bangunan yang akan didirikan akan mencapai 1200 penonton, sesuai dengan standar internasional teater besar. Program yang diusulkan untuk ruang teater ini adalah auditorium dengan kapasitas 1200 sebagai ruang pertunjukan utama, Fasilitas latihan dengan ruang auditorium mini yang menyerupai auditorium utama guna mereka kondisi saat pentas. Ruang ruang lain yang dapat mendukung berlangsungnya pertunjukan, serta pemisahan zoning ruang pementas dan penonton secara total. Serta ruang ruang tambahan lain, seperti restaurant, dan took komersil

Konsep bentukan dari gedung teater ini sebaginya tidak melenceng jauh dari bentukan bangunan sekitar, namun perlu terkesan berbeda(unik) untuk menunjukan karakter wisata (berbeda dari sehari hari). Bentukan masa dasar bangunan mengikuti dari aksis perkotaan yang ada namun pada masa atasanya, dibuat masa yang berbeda denyan bentukan seperti sirip. Bentukan ini akan memperkuat karakter gedung teater yang memiliki typology seperti bentukan cangkang.

Pembangunan proyek ini dapat menjadi wadah pertunjukan kesenian Jakarta. Dengan beragamnya pertunjukan yang dapat disajikan pengunjung yang diharapkan bisa datang dari beragam latar belakang. Pembangunan gedung teater ini akan menjadi miniatur pertunjukan tidak hanya mewakili kebudayaan Jakarta tapi seluruh indonesia.

\section{REFERENSI}

Baron, M. (2009). Michael Barron-Auditorium Acoustics and Architectural Design. New York, NY 10016, USA: Spoon Press 270. Madison Avenue.

bpbd.jakarta.go.id. (2018). Retrieved from http://gis.bpbd.jakarta.go.id/documents/433

Causey, M. (2006). Theatre and Performance in Digital Culture. New York, NY 10016: Routledge 270 dison Ave.

Haylat, B. ((2008)). City Spaces Tourist Places. Routledge.

issuu.com. (2018). Retrieved from https://issuu.com/nahalfathi/docs/architectural_icons

J. Paul Guyer, P. R. (2017). An Introduction to Design of Theatres and Concert Halls. Guyer Partners.

jakutkota. (2018). Retrieved from https://jakutkota.bps.go.id/

KBBI.web. (2018). Retrieved from https://kbbi.web.id/teater

Specht, J. (2014). Architectural Tourism: Building for Urban Travel Destinations. Germany: Springer Gabler.

Susetyo, B. (2007). Harmonia. Sendratasik UNNES.

The Guardian. (2018). Retrieved from The Guardian: https://www.theguardian.com/artanddesign/2017/oct/01/bilbao-effect-frank-gehryguggenheim-global-craze

wordpress. (2018). Retrieved from wordpress: https://seputarteater.wordpress.com/daftarkelompok-teater/ 
www.indonesia.travel. (2018). Retrieved from

https://www.indonesia.travel/sa/en/news/jakarta-life-returns-to-normal-morning-aftermassive-demonstrations 